\title{
COMPUTER-AIDED ASSESSMENT OF THE QUALITY OF SMALL-Sized CAST PARTS
}

\author{
DEAC, C.\& TERA, M.
}

Abstract: Quality is an important issue in casting, but it becomes essential in the case of small-size cast parts, such as dental prosthetic elements. As in most other areas of manufacturing, numerical simulation can be used for predicting potential failure areas in a cast part. This article analyses the various issues in assessing a cast part's quality and presents researches regarding the usage of a simulation software package designed for industrial castings for an accurate prediction of quality-related problems in the case of small-size cast parts used for the manufacturing of medical implants or prostheses.

Key words: casting, quality, numerical simulation
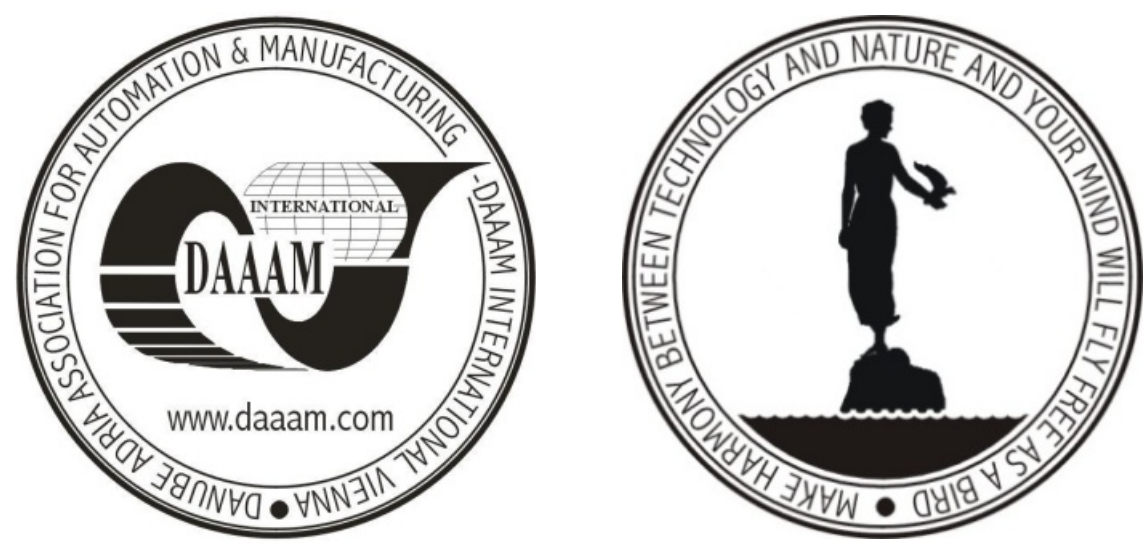

Authors' data: Assoc.Prof. Dr.Eng. Deac, C[ristian]; Dipl.Eng. Tera, M[elania], "Lucian Blaga" University of Sibiu, Emil Cioran str. 4, 550025, Sibiu, Romania, cristian.deac@ulbsibiu.ro,melania.tera@ulbsibiu.ro.

This Publication has to be referred as: Deac, C[ristian] \& Tera, M[elania] (2009). Computer-Aided Assessment of the Quality of Small-Sized Cast Parts, Chapter 60 in DAAAM International Scientific Book 2009, pp. 621-628, B. Katalinic (Ed.), Published by DAAAM International, ISBN 978-3-901509-69-8, ISSN 1726-9687, Vienna, Austria

DOI: $10.2507 /$ daaam.scibook.2009.60 